\title{
PENGARUH STRESOR FISIK TERHADAP DISTRIBUSI SERT DAN INDEKS APOPTOSIS NEURON HIPOKAMPUS, SERTA DISTRIBUSI TNF- $\alpha$ GASTER TIKUS, DENGAN MEDIASI KORTISOL DAN IL-6
}

\author{
Suparno \\ Laboratorium Psikiatri, Fakultas Psikologi Universitas Wisnuwardhana \\ suparnociptoadi@yahoo.com
}

\begin{abstract}
Generally, distres which followed by psychiatric disorders still more medicinal practice controversial especially physically stressor roles on holistic health condition. Therefore, researches still more needed to explain and clarify the influences and the role of physically stressors on psychiatric disorders. This study used an psychoneuroimmunologic paradigm, which used posttest-only true experiment design for the research. About 24 female Rattus norvegicus strain Wistar had been used, they were devided into six groups. To investigate functional changes, we had been used hippocampus SERT distribution changes as mirror of central serotonergic malfunction changes. While, to investigate structural changes we had been inspected apoptosis index of hippocampus CA3 regions (hippocampus slicing). We also took the blood from the rats heart to examinate $I L-6$ and cortisol level, and gastric tissues for TNF- $\alpha$ level examination. Physical stressors lead to arise functional and structural changes include hippocampus SERT distribution, increases hippocampus apoptotic index, and increases TNF- $\alpha$ level, that finally arise the distress. These results of statistical analyses demonstrate that physical stressors tend to be mediated by serotonergic neurotransmission pathway. This study also support assumptions that psychological stressors caused and or related with gastrical changes.
\end{abstract}

Key words: hippocampus CA3 region, SERT malfunction, IL-6, cortisol, TNF- $\alpha$, physical stressors, gastrical changes

\section{PENGANTAR}

Dampak dari paparan berbagai stresor, termasuk stresor fisik dapat berupa kondisi eustres (bertaraf ringan/sedang) maupun distres (bertaraf berat). Kondisi eustres masih dapat mencetuskan dampak yang bersifat positif, yaitu memotivasi individu lebih giat untuk mencapai target kehidupannya, sementara kondisi distres menyebabkan penderitaan jasmaniah maupun kejiwaan.

Pada kondisi distres terjadi perubahan fungsional berupa perubahan hormonal dan neurotransmisi, meliputi peningkatan aktivitas noradrenergik dan kadar kortisol, jika kronis akan mengakibatkan perubahan struktural, berupa atrofi sel-sel piramidal dan penurunan volume hipokampus, serta meningkatan aktivitas aksis hipotalamo-pituitariadrenal (HPA) yang mengakibatkan perubahan kadar interleukin-6 (IL-6), sementara IL-6 mempunyai korelasi positif dengan neurotransmiter norepinefrin (McEwen et al., 1994; Nutt et al., 2002; Figueiredo et al., 2003).

Kondisi distres berkaitan dengan konsentrasi kortisol darah serta konsentrasi IL-6 plasma maupun distribusinya di susunan saraf pusat. Pajanan stresor fisik (renjatan listrik) merangsang hipotalamus, pituitari dan kelenjar adrenal, yang merupakan aksis HPA serta terkait dengan dampak stres, seperti peningkatan kadar kortisol dan katekolamin yang berhubungan erat dengan kadar serotonin dan dopamin dalam otak. Peningkatan kadar kortisol berkorelasi positif dengan peningkatan kadar katekolamin yang meliputi adrenalin, norepinefrin, dan dopamin (Ganong et al., 1995; Rivier et al., 1995; Papanicolaou et al., 1998). IL-6 yang merupakan salah satu sitokin proinflamasi (key immune mediator), beserta reseptornya, terdapat di berbagai area otak termasuk hipotalamus dan hipokampus, yang secara sentral terlibat dalam mediasi emosi serta perilaku. Sitokin berpartisipasi juga dalam jejaring sistem imunitas dan neuroendokrin. IL-6 juga berperan endokrinik setara dengan peran autokrinik maupun parakrinik (Papanicolaou, 2000), merupakan salah satu sitokin utama yang menstimulasi aksis HPA selama "stres keradangan" (Papanicolaou, 2000), IL-6 merupakan stimulator potensial terhadap corticotropin releasing hormone $(\mathrm{CRH})$ hipotalamus dengan dampak aktivasi aksis HPA serta pelepasan glukokortikoid (Raison et al., 2003).

Distres dan berbagai gangguan jiwa berkaitan erat dengan malfungsi proses neurotransmisi, baik tunggal maupun secara kombinasi dari beberapa sistem neurotransmisi (multimalfungsi). Malfungsi serotonergik paling sering berkaitan dengan gangguan jiwa, sehingga dapat digunakan sebagai petanda gangguan jiwa (Bleich et al., 1988; Dubovsky et al., 1995). 
Komposisi multimalfungsi neurotransmisi sentral, dapat diperkirakan dari besar derajat malfungsi neurotransmisi serotonergik, yang tercermin dari serotonin-transporter (SERT) trombosit. Pengukuran afinitas dan densitas SERT ini lebih akurat daripada pengukuran kadar serotonin darah atau urin karena menggambarkan kondisi riil neurotransmisi serotonergik di celah sinaps (Jie-Guang et al., 2000).

SERT adalah protein transporter berafinitas tinggi, terletak di membran plasma dari ujung saraf pre-sinaptik (Charney dan Nestler, 2004). SERT mengkatalisasi pergerakan serotonin (5HT) melewati membran seluler. Di dalam otak, SERT membersihkan serotonin dari ruang ekstraseluler, memodulasi kekuatan dan durasi pensinyalan serotonergik (McKittrick et al., 2000).

Lokasi reseptor dan transporter dari neurotransmiter berada di membran sel sehingga perubahan struktural di hipokampus tersebut akan berdampak pada perubahan reseptor dan perubahan transporter (afinitas serta densitas) dari neurotransmiter. Kondisi ini akan mengakibatkan terjadinya multimalfungsi dari beberapa proses neurotransmisi di otak (sentral) maupun di perifer dengan komposisi yang berbeda secara individual. Multimalfungsi dari proses neurotransmisi di otak (sentral) ini diduga kuat berkaitan erat dengan gangguan jiwa jenis distres. Komposisi multimalfungsi neurotransmisi sentral yang berbeda-beda secara individual, dapat dideteksi atau diprakirakan dari fungsi SERT hipokampus (diwakili densitas maupun afinitas SERT hipokampus, dan tercermin juga pada transporter-serotonin yang berada di trombosit), serta perubahan struktur hipokampus yang meliputi reduksi volume hipokampus dan atrofi neuron piramidal area CA3 hipokampus (Montanez et al., 2003).

Berdasarkan berbagai hasil penelitian di atas, gangguan jiwa jenis distres diperkirakan mempunyai hubungan erat dengan jenis stresornya (fisik, kejiwaan, akut, kronis), juga terkait dengan perubahan fungsi dan struktur hipokampus, serta terkait pula dengan konsentrasi IL-6 plasma maupun kadar kortisol darah serta afinitas atau densitas SERT pada trombosit (darah) maupun hipokampus (sentra integrasi emosi di otak).

Stresor psikologis juga dapat menimbulkan kondisi patologis pada saluran cerna, seperti ulkus peptikum, gastroenteritis, Inflammatory Bowel Disease (IBD) dan Irritable Bowel Syndrome (IBS) menempati peringkat keempat (Sunarto, 2005). Stres dapat berpengaruh pada sistem imun tubuh dengan cara meningkatkan sekresi sitokin proinflamasi.

Stres dapat menginduksi peningkatan glukortikoid. Tingkat glukortikoid yang tinggi dan akut dapat mengurangi sel-sel proinflamasi pada waktu awal (early timepoint), tetapi kemudian jumlah sel proinflamasi tersebut meningkat, hal ini diduga terjadi penundaan dan sitokin proinflamasi berpengaruh pada glukortikoid (bidireksional). Sedangkan pada tingkat glukortikoid yang tinggi dan kronis akan menyebabkan infiltrasi yang cepat dan akan meningkatkan infiltrasi seluler. Efek imunosupresif glukortikoid (pengurangan infiltrasi seluler inflamator) terjadi pada perifer dan efek proinflamasi glukortikoid (peningkatan jumlah total sel inflamator) terjadi pada inflamasi sistem saraf pusat. Tingkat glukortikoid yang tinggi dan akut akan menghambat IL-1 $\alpha$, IL- $1 \beta$, tumor necrotic factor - $\alpha$ (TNF- $\alpha$ ), tetapi tidak pada IL-6, dan sebaliknya pada tingkat glukortikoid yang tinggi dan kronis dapat meningkatkan keempat sitokin proinflamasi tersebut (Dinkel, 2002).

Berbagai sitokin proinflamasi yang terlibat dalam inflamasi, yaitu IL-6, TNF- $\alpha$, IL-1, yang lazim disebut key immune mediator. Inflamasi merupakan serangkaian kompleks interaksi homeostasis yang melibatkan reaksi seluler, hormonal dan molekuler yang bertujuan untuk melindungi tubuh (Eales, 2003), yang diawali dengan proses stimulasi akut pada aksis HPA. Key immune mediator diidentifikasi sebagai molekul efektor yang berhubungan dengan sinyal sistem imun pada aksis HPA (Mayer, 2000).

Menurut Goebel (2002) sitokin proinflamasi seperti TNF- $\alpha$, berperan penting dalam mengkoordinasi tubuh untuk merespons inflamasi. TNF- $\alpha$ secara efektif menginduksi respons inflamasi lokal dan membantu mengontrol infeksi.

Sejauh ini belum pernah dilakukan penelitian yang bersifat menyeluruh tentang keterkaitan antara perubahan konsentrasi IL-6 maupun konsentrasi kortisol plasma dengan distribusi SERT beserta indeks apoptosis pada neuron hipokampus di otak, di samping perubahan distribusi TNF- $\alpha$ di saluran cerna dalam konteks gangguan jiwa jenis distres.

\section{BAHAN DAN CARA KERJA}

\section{Bahan Penelitian}

Sampel penelitian adalah 24 ekor tikus betina Rattus novergicus strain Wistar usia 10-12 minggu berat 150-185 gram, yang dipapar dengan stresor renjatan listrik $16 \mathrm{~mA}$ dengan alat "Electric Foot Shock" di lantai kandang, frekuensi dan sesi renjatan listrik meningkat bertahap agar stresor tidak mudah diadaptasi oleh tikus (Sumintarti, 1997). Perlakuan berlangsung selama 7 hari, 14 hari dan 28 hari (akut dan kronis). Selanjutnya diambil plasma darah serta 
jaringan neuronal (neuron piramidal) hipokampus area CA3, dengan sediaan irisan setebal $2 \mu \mathrm{m}$, serta jaringan lambung dengan ketebalan $5 \mu \mathrm{m}$.

\section{Cara Kerja}

Rancangan penelitian adalah eksperimental murni yang kegiatannya dapat dibagi dalam 2 tahap, yaitu tahap pendahuluan dan tahap eksperimental.

\section{Penentuan konsentrasi IL-6 plasma tikus}

Diukur dengan cara immunoassay menggunakan anti-mouse IL-6 immunoassay Quantikine. Dibaca pada ELISA reader (BIORAD-505) pada 450/490 nm (Rosen et al., 1998).

\section{Penentuan konsentrasi kortisol plasma tikus}

Dengan cara enzyme immunoassay (microtiter strips; for the quantitative determination of cortisol in mouse plasma and plasma) menggunakan Cortisol ELISA. Kadar kortisol normal sore hari (pk 16.00) 30-150 ng/ml (83-414 nmol/l). Kalkulasi hasil pada kertas grafik semilogaritma konsentrasi standar (abscissa, logarithmic) diplot berlawanan dengan kadar optik yang tercantum (ordinat, linear).

\section{Penentuan distribusi kortisol, IL-6, dan SERT serta indeks Apoptosis hipokampus}

Dari otak tikus-coba dilakukan pembuatan sayatan di area CA3 hipokampus, kemudian dilakukan pengamatan imunohistokimiawi dengan antibodi (Dako immunohistochemical detection kit), secara berturut-turut: pembuatan parafin block jaringan, proses deparafinisasi, proses pewarnaan hematoxilin-eosin (Mayer), pelabelan fragmentasi DNA (Pemeriksaan Apoptosis dengan metode Tunel), metode pewarnaan imunositokimia terhadap Kortisol, IL-6, dan SERT, proses penghitungan IL-6, kortisol dan SERT serta apoptosis.

\section{Penentuan distribusi TNF- $\alpha$ di Lambung}

Organ lambung yang telah difiksasi dalam formalin dipotong pada bagian fundus, didehidrasi dalam etanol bertingkat, direndam dalam xilol, di-embedding dalam blok parafin, dipotong dengan ketebalan $5 \mu \mathrm{m}$. Slide dilabel dengan antibodi primer, Rabbit Polyclonal IgG TNF- $\alpha$ (Santacruz Biotechnology), serta antibodi sekunder, Goat Antirabbit IgG Biotin Labelled. Slide diproses dengan SA-HRP (Strepavidin-Horseradish Peroxidase) dan DAB (3,3 diamino benzidine tetrahydrochloride). Kemudian dilakukan counter stain dengan Mayer Hematoxilen.
Pembuatan model distres dengan renjatan listrik (RL)

Pembuatan model distres dengan renjatan listrik terhadap hewan coba secara terperinci dapat dicermati dalam Tabel 1.

Tabel 1. Perlakuan dengan renjatan listrik

\begin{tabular}{|c|c|c|c|c|}
\hline Waktu & Perlakuan & $\begin{array}{c}\text { Sesi/ } \\
\text { Durasi }\end{array}$ & Frekuensi & Eksekusi \\
\hline 7 hari & $\begin{array}{c}\text { Kontrol } \\
\text { RL }\end{array}$ & $\begin{array}{l}1 / 2 \text { det } \\
1 / 2 \text { det }\end{array}$ & $\begin{array}{l}1 \times \\
1 \times\end{array}$ & Hari ke-7 \\
\hline 14 hari & $\begin{array}{c}\text { Kontrol } \\
\text { RL }\end{array}$ & $\begin{array}{l}1 / 2 \text { det } \\
1 / 2 \operatorname{det}\end{array}$ & $\begin{array}{l}2 x \\
2 x\end{array}$ & Hari ke-14 \\
\hline 28 hari & $\begin{array}{c}\text { Kontrol } \\
\text { RL }\end{array}$ & $\begin{array}{l}1 / 2 \operatorname{det} \\
1 / 2 \operatorname{det}\end{array}$ & $\begin{array}{l}3 \times \\
3 x\end{array}$ & Hari ke-28 \\
\hline
\end{tabular}

\section{Pengamatan Penelitian}

Penelitian terbagi dalam 6 kelompok perlakuan, masing-masing kelompok terdiri atas 4 ekor tikus.

\section{Pengamatan Penelitian Tahap 1}

Penelitian tentang konsentrasi IL-6 dan konsentrasi kortisol pada tikus distres, menggunakan paparan predator, pada kelompok perlakuan 7 hari dan kelompok perlakuan 14 hari. Darah tikus diambil dari jantung dan kemudian dilakukan pemeriksaan laboratorium yang menggunakan: (a) Enzyme immunoassay menggunakan cortisol ELISA untuk pemeriksaan konsentrasi kortisol plasma. (b) Quantikine mouse IL-6Immunoassay, untuk pemeriksaan konsentrasi IL-6 plasma.

Berat badan kelompok perlakuan 7 hari dan 14 hari dicatat. Berat badan dan perilaku psikomotorik dari awal sampai dengan akhir penelitian diamati dan dicatat, yang mengalami perlakuan maupun yang tidak.

\section{Pengamatan Penelitian Tahap 2}

Penelitian tentang konsentrasi IL-6 dan konsentrasi kortisol pada tikus yang distres dengan menggunakan renjatan listrik (RL), pada kelompok perlakuan 28 hari.

Penelitian distribusi IL-6 dan distribusi kortisol pada tikus yang distres dengan menggunakan RL, pada kelompok 7 hari, 14 hari, dan 28 hari. Pemeriksaan dengan metode imunohistokimiawi distribusi IL-6 pada area CA3 
hipokampus tikus yang dipapar dengan stresor RL yang dilakukan terhadap semua kelompok tikus (kontrol, serta perlakuan renjatan listrik 7 hari, 14 hari dan 28 hari), dengan unit analisis jaringan otak tikus regio hipokampus area CA3.

Pengaruh renjatan listrik terhadap perubahan struktur (berupa indeks apoptosis neuron piramidal CA-3) serta malfungsi SERT di area CA-3 hipokampus (distribusi SERT) diperiksa dan dicatat, untuk kurun waktu perlakuan 7, 14, dan 28 hari. Pemeriksaan imunohistokimiawi dilakukan dengan menggunakan: (a) Chemicon's mouse monoclonal antibody to the Serotonine Transporter (cat.-No.: MAB1564), untuk pemeriksaan distribusi SERT hipokampus, maupun distribusi IL -6 dan distribusi kortisol hipokampus (antibodi primer): (1) Antibodi primer: antikortisol, anti IL-6, antiSERT, (2) Antibodi sekunder: anti-rabbit biotin conjugated. (b) Dako immunohistochemical detection kit; stainning kit untuk pemeriksaan distribusi SERT hipokampus, maupun distribusi IL-6 dan distribusi kortisol hipokampus. (c) In Situ Cell Death Detection Kit, POD (cat. No. 11 684817 910), kit untuk deteksi imunohistokimiawi serta kuantifikasi apoptosis dengan cara teknologi Tunel (pemeriksaan indeks apoptosis).

Hubungan antara konsentrasi dan distribusi IL-6 dan kortisol terhadap struktur (indeks apoptosis neuron piramida CA-3 hipokampus) serta malfungsi SERT neuron piramidal CA-3 hipokampus dianalisis dengan uji statistik parametrik.

Penelitian distribusi IL- $1 \beta$ pada lambung dari tikus yang distres dengan menggunakan paparan RL, pada kelompok 7 hari, 14 hari, dan 28 hari.

\section{PENGOLAHAN DATA}

\section{Analisis Peubah Ganda jenis Komparasi}

Data yang diperoleh diolah secara statistik menggunakan Metode Statistik Parametrik, yang meliputi analisis peubah ganda jenis komparasi dan analisis peubah ganda jenis asosiasi. analisis peubah ganda jenis komparasi meliputi analisis ragam (ANOVA), multivariat analisis ragam (MANOVA), uji t 2 populasi (uji beda). Sedangkan analisis peubah ganda jenis asosiasi meliputi analisis korelasi, analisis regresi, analisis jalur (Path).

\section{HASIL}

Dalam penelitian tahap pertama dan kedua, dihasilkan enam temuan utama (hasil temuan: $1,2,3,4,5,6)$ sebagai berikut.

\section{Hasil Temuan "1"}

Didapatkan bukti adanya pengaruh peningkatan intensitas renjatan listrik (RL) terhadap konsentrasi IL-6 dan kortisol plasma. Hasil penelitian di atas sesuai dengan hasil pengujian regresi linier sederhana dengan nilai signifikansi (p) sebesar 0,000 (lebih kecil daripada $\alpha$, tingkat kesalahan $5 \%$ ), yang menyatakan intensitas paparan RL memengaruhi peningkatan konsentrasi IL-6 plasma sebesar 78,44\%, serta kortisol plasma sebesar $56,33 \%$.

\section{Hasil Temuan "2"}

Pada penelitian ini diperoleh hasil temuan "2" yang membuktikan bahwa peningkatan konsentrasi IL-6 dan kortisol plasma, akan meningkatkan pula distribusi IL-6 dan kortisol hipokampus.

Pernyataan di atas didukung oleh pengujian statistik parametrik berikut ini, yang menggunakan analisis korelasi, dengan hasil terdapat korelasi yang kuat dan positif antara konsentrasi IL-6 plasma dengan distribusi IL-6 hipokampus (nilai korelasi sebesar 0,890), antara konsentrasi IL-6 plasma dengan distribusi kortisol hipokampus $(0,878)$. Antara konsentrasi kortisol plasma dengan distribusi IL-6 hipokampus $(0,864)$, antara konsentrasi kortisol plasma dengan distribusi kortisol hipokampus $(0,837)$.

\section{Hasil Temuan "3"}

Diperoleh pula hasil temuan " 3 " yang membuktikan bahwa peningkatan distribusi IL- 6 dan kortisol hipokampus, meningkatkan juga distribusi SERT dan indeks apoptosis hipokampus.

Pernyataan di atas didukung oleh pengujian statistik parametrik, yaitu terdapat korelasi yang kuat dan positif antara distribusi IL-6 hipokampus dengan distribusi SERT hipokampus (nilai korelasi 0,873 ), antara distribusi IL-6 hipokampus dengan indeks apoptosis hipokampus $(0,881)$. Antara distribusi kortisol hipokampus dengan distribusi SERT hipokampus $(0,864)$, antara distribusi kortisol hipokampus dengan indeks apoptosis hipokampus $(0,900)$.

\section{Hasil Temuan "4"}

Temuan keempat pada penelitian ini adalah hasil temuan "4" yang menyajikan bukti bahwa terdapat korelasi distribusi SERT dan indeks apoptosis hipokampus dengan perubahan berat badan tikus (menurun pada minggu I, selanjutnya meningkat). Pengaruh ini diuji dengan menggunakan analisis regresi linier sederhana, dengan hasil pengujian adalah distribusi SERT korelatif dengan 
peningkatan berat badan tikus sebesar 2,75\%, serta indeks Apoptosis memengaruhi peningkatan berat badan tikus sebesar $2,36 \%$.

\section{Hasil Temuan "5"}

Yang kelima, hasil penghitungan agregasi limfosit pada pembuluh limfe yang terdapat pada muskularis mukosa dan submkosa lambung menunjukkan bahwa renjatan listrik mempunyai skor (nilai) agregasi limfosit yang cukup tinggi, yaitu 2,13 (30-41\%), sementara tanpa paparan sebesar 1,41 (0-25\%). Jumlah lokasi (titik) TNF- $\alpha$ pada RL adalah 18 titik (6 titik pada mukosa, 5 titik pada muskularis mukosa, 3 titik pada submukosa dan 4 titik pada muskularis mukosa) yang lebih banyak dari kontrol yang hanya sebesar 8 titik.

\section{Hasil Temuan "6"}

Pada penelitian ini diperoleh juga hasil temuan "6" yang memasok bukti tentang adanya korelasi antara intensitas renjatan listrik dengan perubahan berat badan tikus (menurun pada minggu I, minggu selanjutnya meningkat).

Hasil pengujian regresi pengaruh intensitas renjatan listrik terhadap berat badan tikus, dengan nilai signifikansi (p) sebesar 0,000 (lebih kecil daripada $\alpha 5 \%$ atau 0,05 ), maka dapat disimpulkan terdapat pengaruh intensitas RL terhadap berat badan tikus. (a) Intensitas renjatan listrik memengaruhi penurunan berat badan tikus sebesar $6,07 \%$ pada minggu pertama renjatan listrik (untuk kelompok perlakuan 7, 14, dan 28 hari; sedangkan kelompok kontrol meningkat). (b) Intensitas renjatan listrik (RL) memengaruhi peningkatan berat badan tikus sebesar 3,01\% pada minggu kedua renjatan listrik (untuk kelompok perlakuan 14 dan 28 hari; sedangkan kelompok kontrol meningkat). (c) Intensitas renjatan listrik memengaruhi peningkatan berat badan tikus sebesar 34,31\% pada minggu ketiga renjatan listrik (untuk kelompok perlakuan 28 hari; sedangkan kelompok kontrol meningkat).

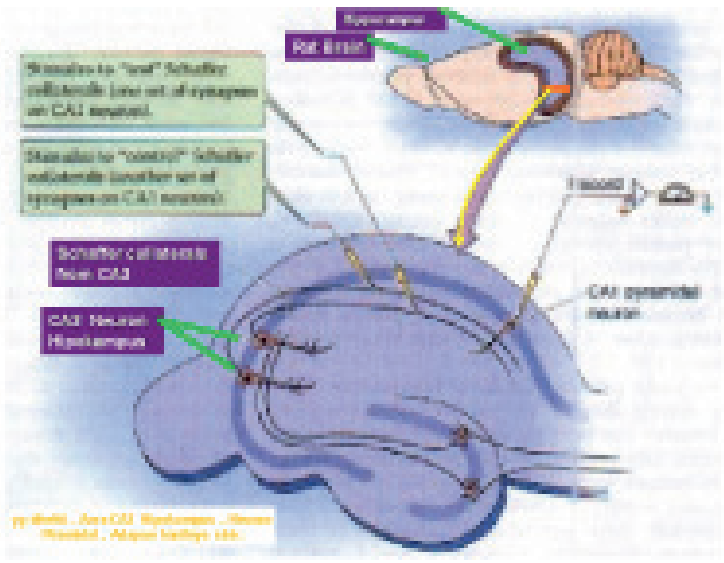

Gambar 1. Lokasi pengambilan sampel

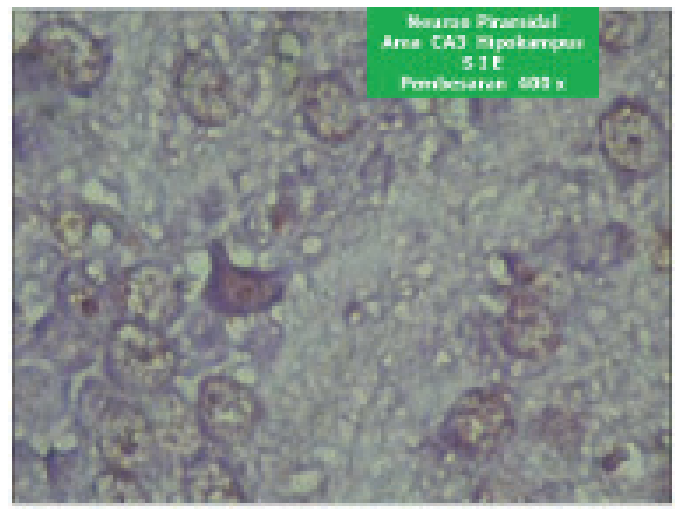

$2 a$

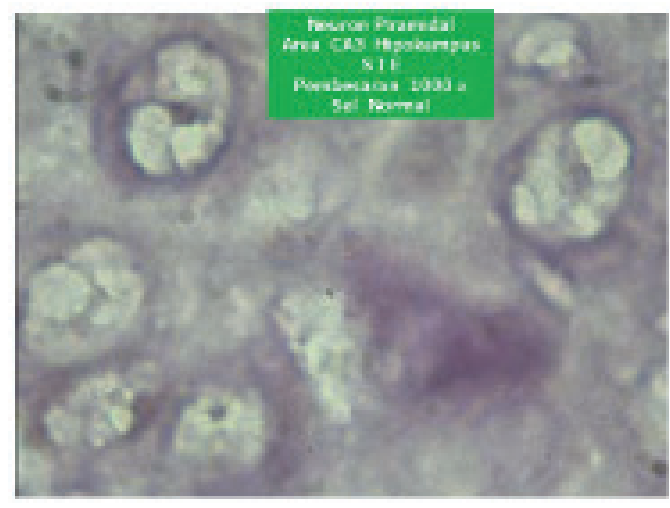

$2 b$

Gambar 2. Lokasi area CA3 hipokampus (2a) Regio CA3 hipokampus yang merupakan sentra integrasi emosi, serta rentan terhadap pengaruh stresor fisik (2b) Neuron piramidal di regio CA3 hipokampus yang mengalami perubahan struktur dikarenakan stresor fisik 


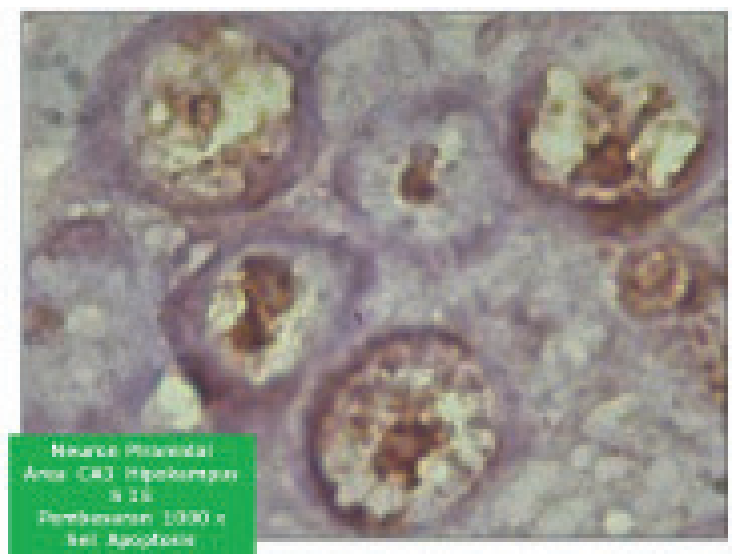

Gambar 3. Neuron piramidal di regio CA3 hipokampus yang mengalami apoptosis dengan nukleus dan aparatus nya yang mengalami fragmentasi dan menyerap apoptag lebih dari neuron normal.

\section{Pengujian Distribusi Kortisol Hipokampus}

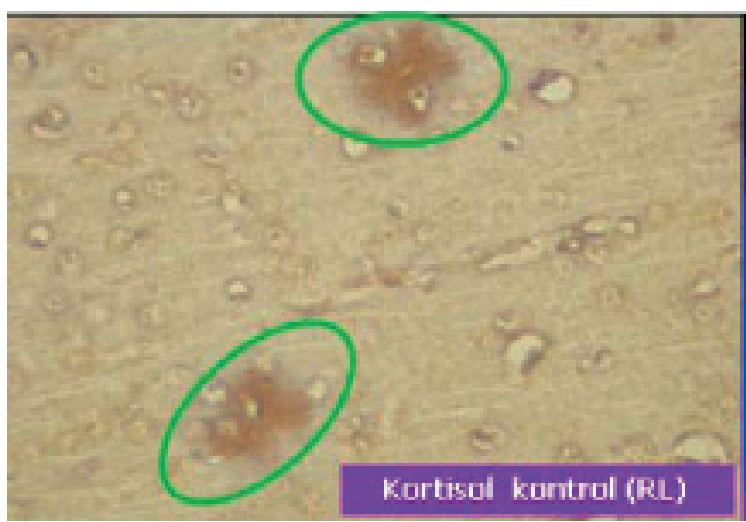

Gambar 4. Distribusi kortisol pada area CA3 hipokampus, pada kelompok kontrol, pewarnaan imunositokimia yang terlihat coklat tua jumlahnya terhitung paling sedikit

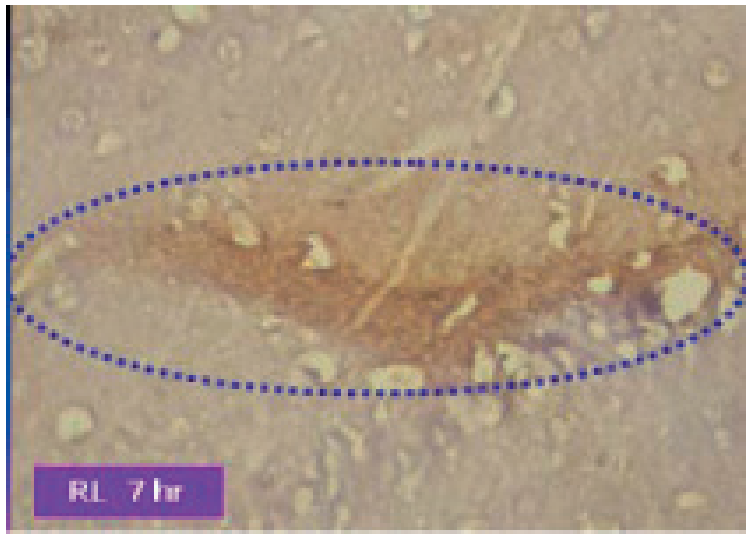

Gambar 5. Distribusi kortisol pada area CA3 hipokampus, pada kelompok perlakuan RL 7 hari, pewarnaan immunositokimia yang terlihat coklat tua jumlahnya terhitung lebih banyak atau lebih luas (memanjang)

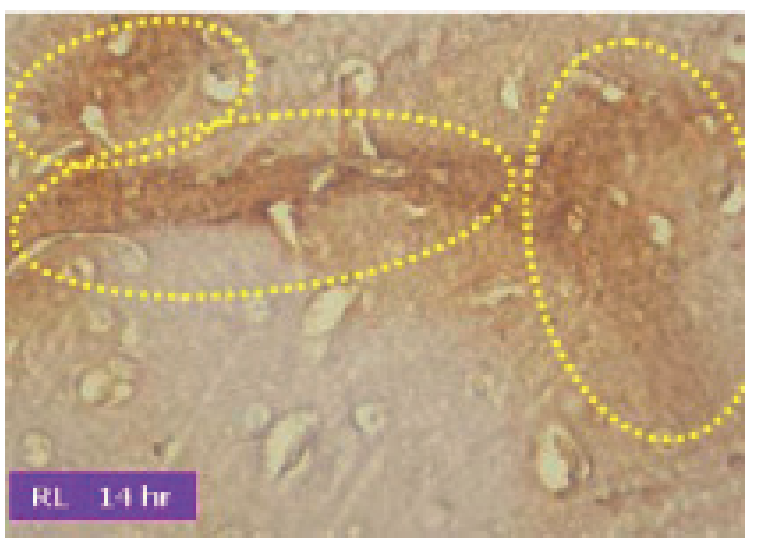

Gambar 6. Distribusi kortisol pada area CA3 hipokampus, pada kelompok perlakuan 14 hari terlihat lebih luas dari kelompok perlakuan RL 7 hari.

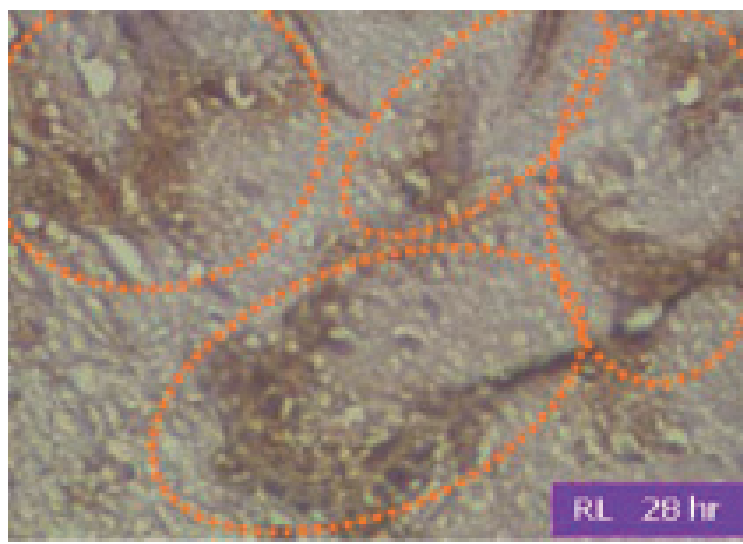

Gambar 7. Distribusi kortisol pada area CA3 hipokampus, pada kelompok kontrol terlihat paling sedikit, kelompok perlakuan RL 28 hari terlihat paling luas. 


\section{Pengujian Distribusi Interleukin-6 Hipokampus}
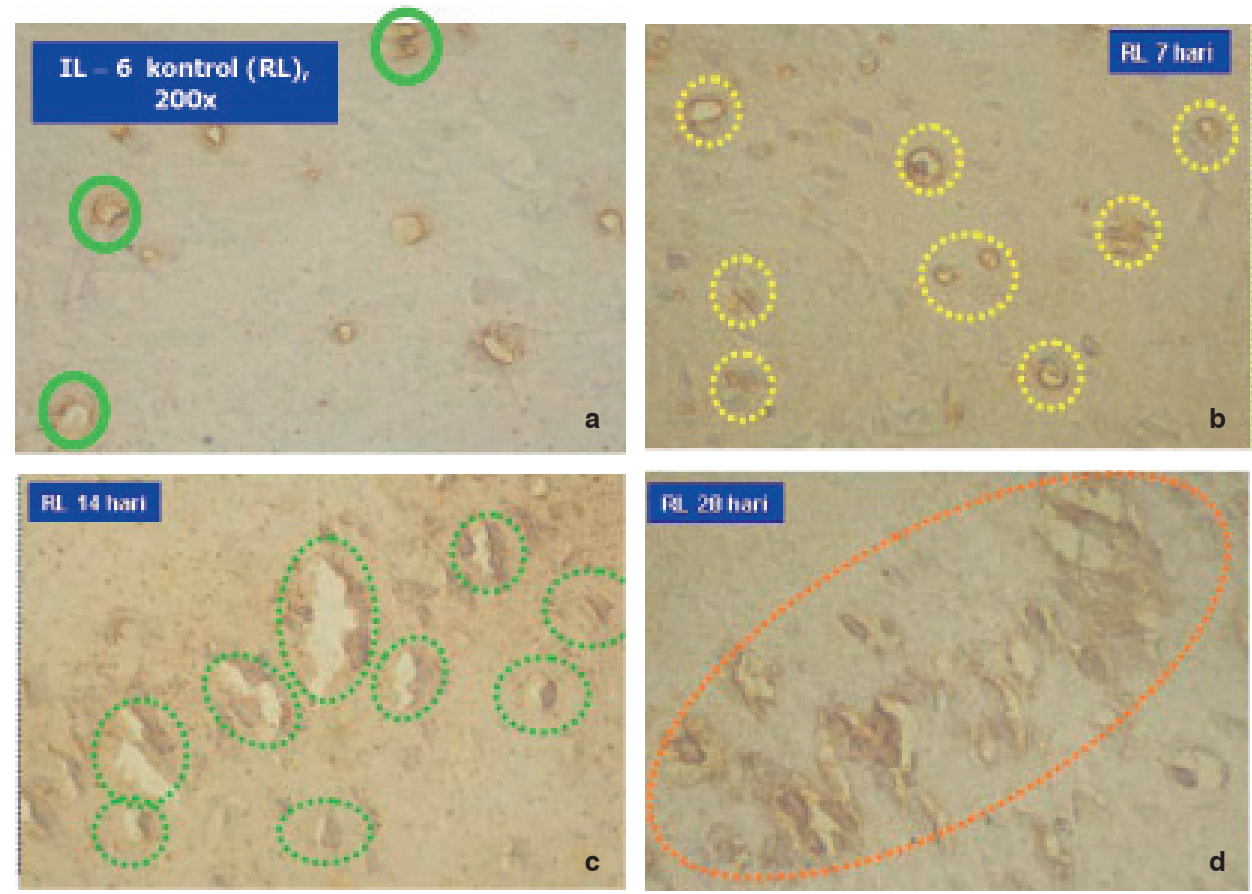

Gambar 8. Distribusi IL-6 di area CA3 hipokampus, (a) pada kelompok kontrol distribusi tampak normal, (b) pada kelompok perlakuan RL 7 hari distribusi meningkat (jumlah daerah kecoklatan meningkat), (c) pada kelompok perlakuan 14 hari daerah berwarna kecoklatan bertambah luas dan jumlahnya meningkat, (d) pada kelompok perlakuan 28 hari, daerah berwarna kecoklatan bertambah banyak jumlahnya serta bertambah luas (pembesaran $200 \times$ )

\section{Pengujian Distribusi SERT Hipokampus}
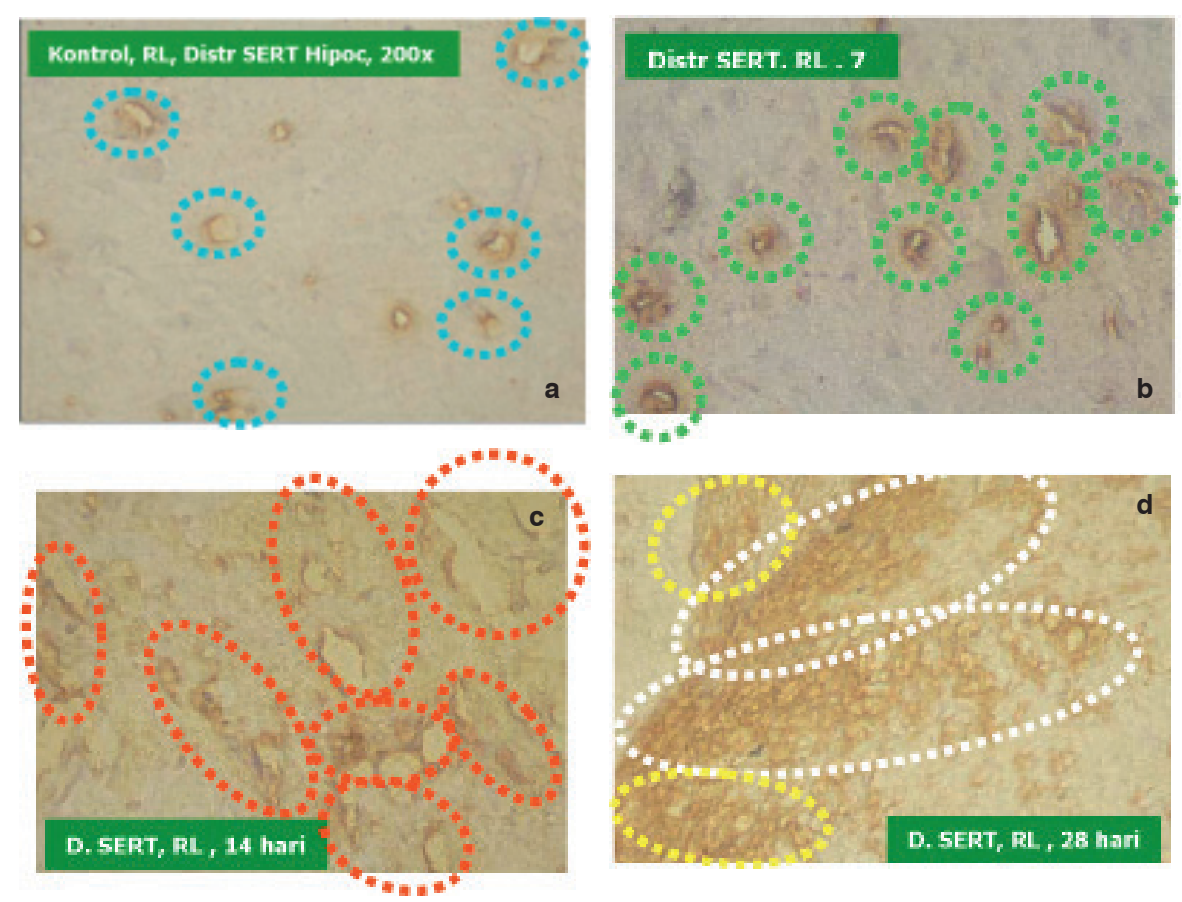

Gambar 9. Distribusi SERT di area CA3 hipokampus, (a) pada kelompok kontrol area kecoklatan sempit dan sedikit jumlahnya; (b) pada kelompok perlakuan RL 7 hari area kecoklatan agak luas dan jumlahnya meningkat; (c) pada kelompok 14 hari, area kecoklatan luas dan jumlahnya lebih banyak daripada kelompok perlakuan RL 7 hari, (d) distribusi SERT area CA3 hipokampus yang tertinggi ditemukan pada RL 28 hari 


\section{Pengujian Jaringan Lambung}
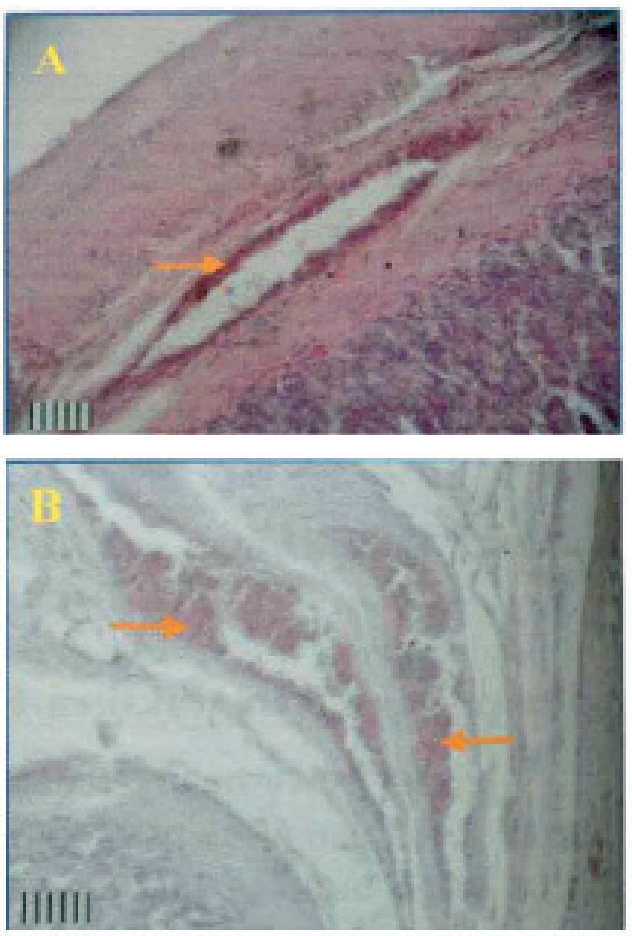

Gambar 11. Hasil Pewarnaan Hematoksilen-Eosin pembuluh limfe pada gaster tikus dengan perlakuan (A) tanpa paparan, (B) perlakuan renjatan listrik, (100x). Tanda panah menunjukkan agregasi sel limfosit pada pembuluh limfe. 1 skala $=10 \mu \mathrm{m}$.
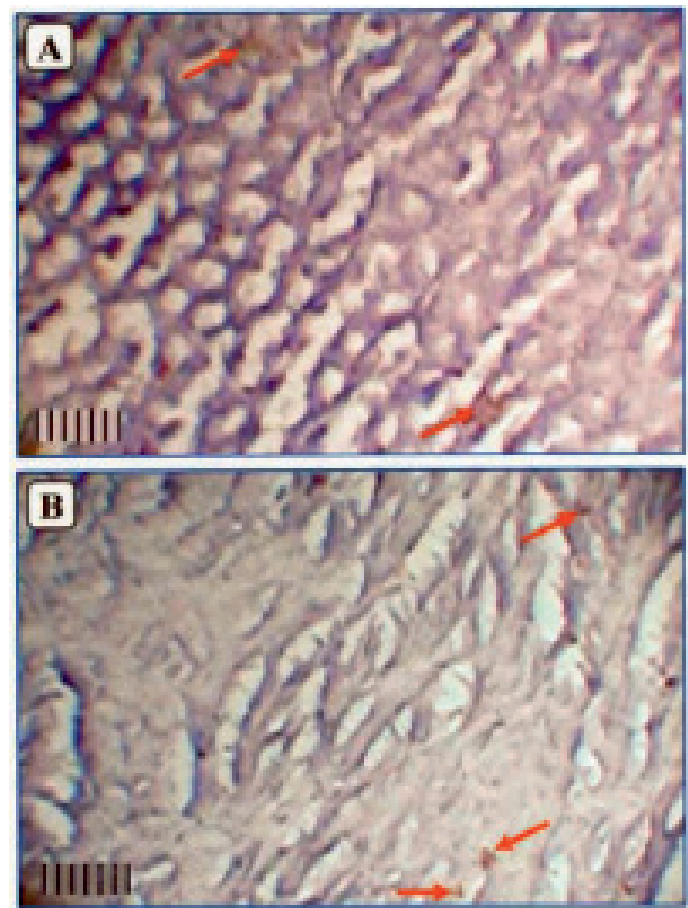

Gambar 12. Hasil Imunohistokimia mukosa gaster tikus, (A) tanpa paparan, (B) perlakuan renjatan listrik (100x). Tanda panah menunjukkan keberadaan TNF- $\alpha .1$ skala $=10 \mu \mathrm{m}$.
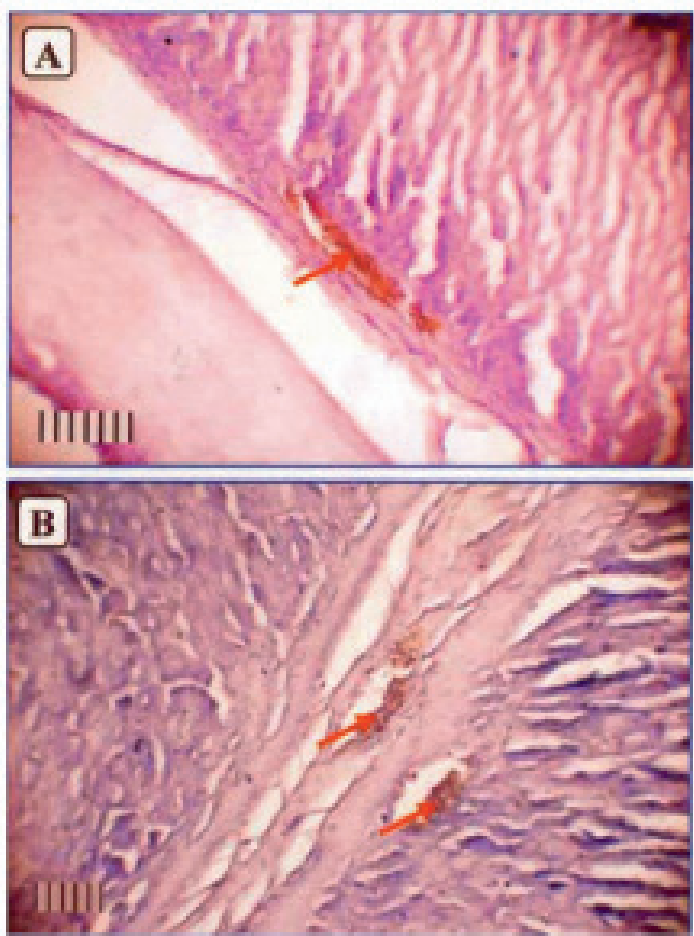

Gambar 13. Hasil Imunohistokimia Muskularis mukosa gaster tikus, (A) tanpa paparan, (B) perlakuan renjatan listrik (100×). Tanda panah menunjukkan keberadaan TNF- $\alpha .1$ skala $=10 \mu \mathrm{m}$.
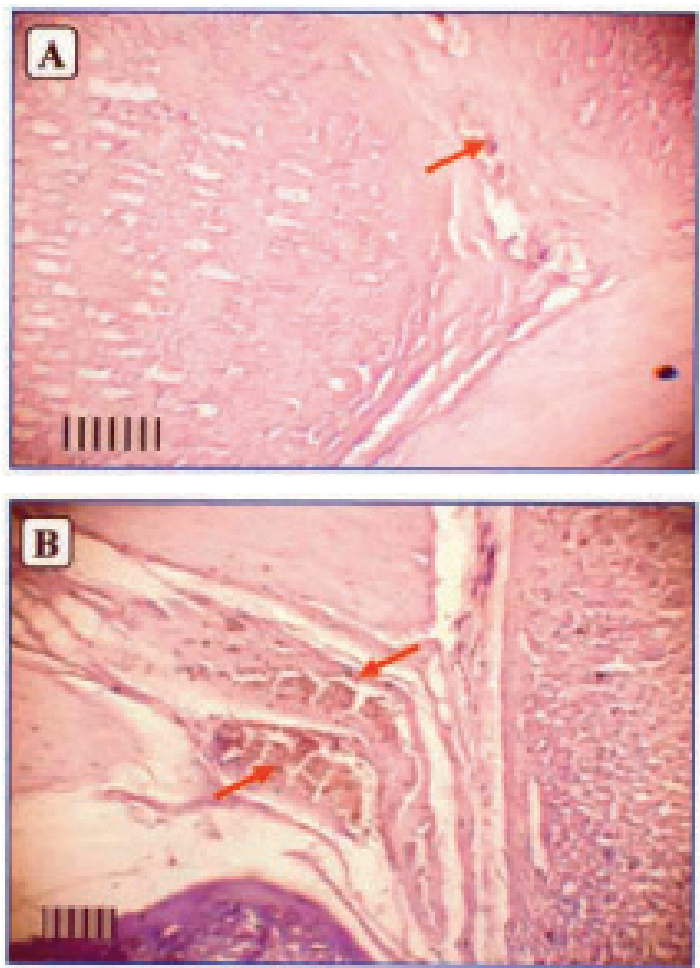

Gambar 14. Hasil Imunohistokimia Sub mukosa gaster tikus, (A) tanpa paparan, (B) perlakuan renjatan listrik (100x). Tanda panah menunjukkan keberadaan TNF- $\alpha .1$ skala $=10 \mu \mathrm{m}$. 

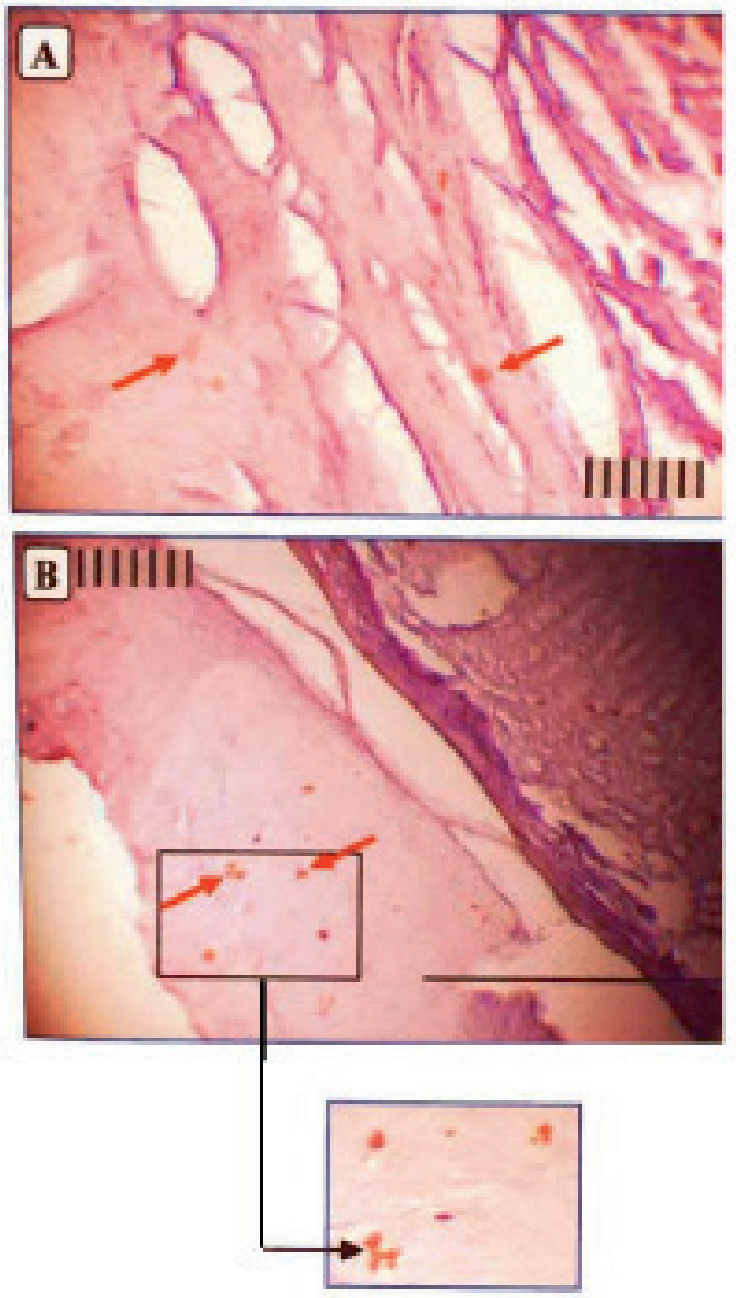

Gambar 15. Hasil imunohistokimia muskularis eksterna gaster tikus, (A) tanpa paparan, (B) perlakuan renjatan listrik (100x). Tanda panah menunjukkan kebera daan TNF- $\alpha .1$ skala $=10 \mu \mathrm{m}$.

Tabel 2. Rata-rata skoring penutupan luas permukaan pembuluh limfe pada setiap perlakuan

\begin{tabular}{lc}
\hline \multicolumn{1}{c}{ Perlakuan } & Rata-rata \\
\hline Tanpa paparan & 1,41 \\
Paparan Renjatan Listrik & 2,13 \\
Paparan Predator & 3,56 \\
\hline
\end{tabular}

Tabel 3. Distribusi TNF- $\alpha$ pada lambung

\begin{tabular}{lcc}
\hline \multirow{2}{*}{ Lapisan lambung } & \multicolumn{2}{c}{$\begin{array}{c}\text { Jumlah titik lokal sekresi TNF- } \alpha \\
\text { pada perlakuan }\end{array}$} \\
\cline { 2 - 3 } & $\begin{array}{c}\text { Tanpa } \\
\text { paparan }\end{array}$ & Renjatan listrik \\
\hline Mukosa & 2 & 6 \\
Muskularis mukosa & 4 & 5 \\
Submukosa & 1 & 3 \\
Muskularis eksterna & 1 & 4 \\
Jumlah total TNF- $\alpha$ & 8 & 18 \\
\hline
\end{tabular}

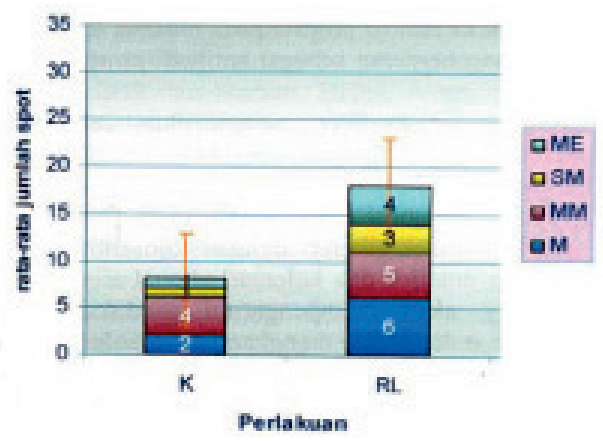

Gambar 16. Rata-rata lokasi keberadaan TNF- $\alpha$ pada perlakuan tanpa paparan (K), dan renjatan listrik (RL). Keterangan: ME: Muskularis Eksterna, SM: Sub Mukosa, MM: Muskularis Mukosa dan M: Mukosa.

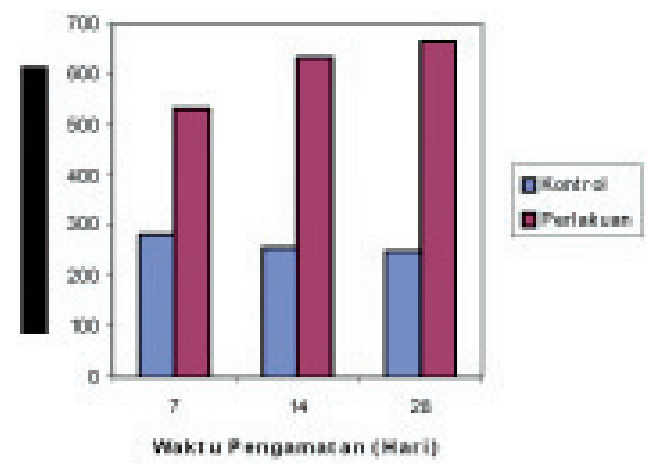

Gambar 17. Perbandingan konsentrasi kortisol plasma antara kondisi normal dengan kondisi distres. Pada kondisi normal, konsentrasi kortisol plasma sebesar 262,7956 (rerata untuk seluruh kelompok kontrol dari perlakuan 7 hari, 14 hari dan 28 hari). Pada kondisi distres, konsentrasi kortisol plasma sebesar 607,4500 (rerata dari seluruh kelompok perlakuan). Nilai terendah untuk mendeteksi keterjadian kondisi distres adalah konsentrasi kortisol plasma $\geq 531,6166$

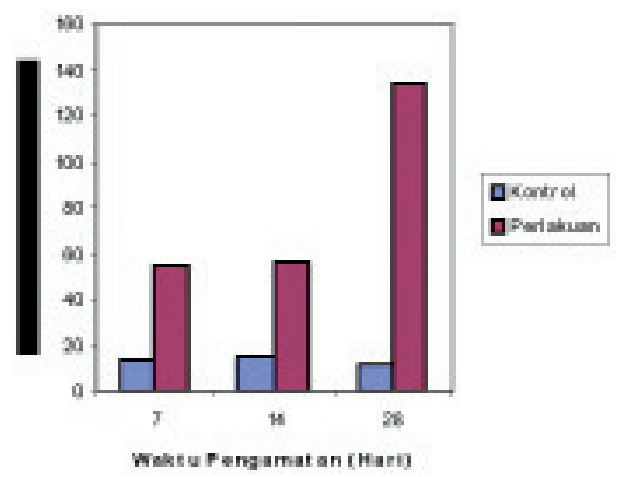

Gambar 18. Perbandingan konsentrasi IL-6 plasma antara kondisi normal dengan kondisi distres. Pada kondisi normal, konsentrasi IL-6 plasma sebesar 13,0220 (rerata untuk seluruh kelompok kontrol dari perlakuan 7 hari, 14 hari dan 28 hari). Pada kondisi distres, konsentrasi IL-6 plasma sebesar 81,2098 (rerata dari seluruh kelompok perlakuan). Nilai terendah untuk mendeteksi keterjadian kondisi distres adalah konsentrasi IL-6 plasma $\geq 54,3975$ 


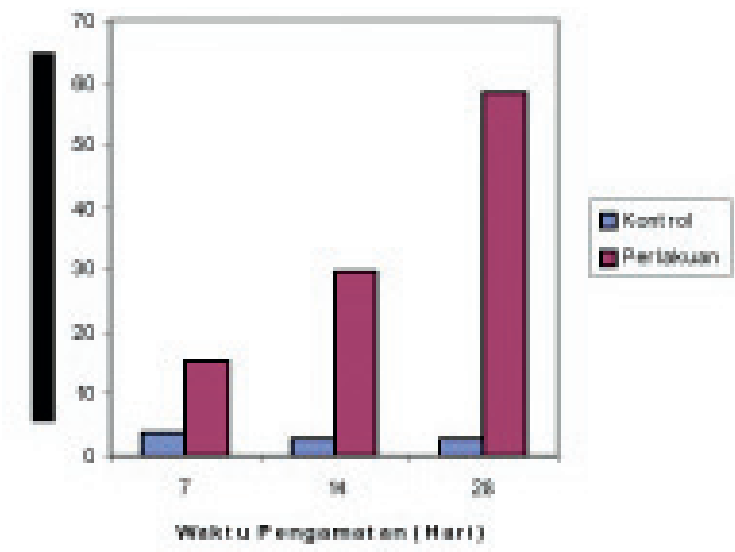

Gambar 19. Perbandingan distribusi SERT di area CA3 hipokampus untuk normal dan distres. Nilai terendah untuk mendeteksi keterjadian kondisi distres untuk SERT hipokampus adalah $\geq 15,1875$

\section{PEMBAHASAN}

Hasil temuan pertama ("1") membuktikan bahwa paparan predator yang berfungsi sebagai stresor akan menyebabkan terjadinya perubahan fungsi dan struktur hipokampus, melalui peran kortisol dan IL-6 plasma yang terbukti dari peningkatan kadarnya di plasma.

IL-6 lebih responsif terhadap stresor kejiwaan, mengingat peningkatannya lebih tinggi $(70,16 \%)$ daripada peningkatan konsentrasi kortisol plasma (45,98\%). Data ini merupakan suatu temuan penelitian yang baru.

Sampai saat ini diyakini bahwa pemegang peran sentral dari suatu respons terhadap stres adalah kortisol, penelitian terdahulu membuktikan bahwa stres berkepanjangan pada hewan coba (tikus) menimbulkan kerusakan hipokampus bersifat plastis dengan petanda biologisnya berupa reduksi neuron piramidal area CA3 hipokampus, efek ini dimediasi oleh glukokortikoid yang meningkatkan aliran ion kalsium di dalam hipokampus, dengan peran kunci dalam destruksi neuron piramidal di area CA3 hipokampus (Chrousos et al., 1995; McEwen et al., 1998; Papanicolou et al., 2000; Raison et al., 2003).

Hasil temuan kedua ("2") membuktikan bahwa, peran IL-6 sebagai mediator stres masih lebih dominan dibandingkan dengan kortisol, mengingat IL-6 plasma dapat meningkatkan distribusi IL-6 dan kortisol hipokampus lebih tinggi (63,79\% dan 77,86\%) dibandingkan dengan kortisol plasma (38,19\% dan 41,98\%). Data ini merupakan suatu temuan penelitian baru, penelitian sebelumnya lebih banyak mengungkap peran kunci kortisol dalam memediasi stres.

Hasil temuan ketiga ("3") membuktikan bahwa, kortisol secara langsung dapat mengakibatkan perubahan struktur hipokampus. Hasil temuan penelitian ketiga ini sesuai dengan penelitian terdahulu yang membuktikan bahwa stres berkepanjangan pada hewan coba (tikus) menimbulkan kerusakan di hipokampus yang bersifat plastis dengan petanda biologisnya berupa reduksi neuron piramidal di area CA3 hipokampus, dan efek ini dimediasi oleh glukokortikoid meningkatkan aliran ion kalsium di dalam hipokampus. IL-6 dapat memengaruhi neurogenesis melalui sejumlah mekanisme yang berbeda-beda yang merupakan variasi dari kondisi fisiologis. IL-6 juga bekerja sentral merangsang aksis HPA, kemudian meningkatkan glukokortikoid sirkulasi (Turnbull dan Rivier, 1999). Sebelumnya para peneliti mendapatkan bukti adanya komunikasi multidireksional antara berbagai sistem imunitas, otonom, hormonal dan susunan saraf pusat (Blalock, 1994; Hopkins dan Rothwell, 1995; Maier dan Watkins, 1998).

Temuan keempat ("4") membuktikan bahwasanya berbagai stresor akan menimbulkan distres dengan gradasi yang kurang lebih sama, melalui gangguan fungsi dan struktur hipokampus dengan tingkatan yang sama pula.

Temuan kelima ("5") membuktikan bahwa stresor fisik (RL) dapat meningkatkan aktivitas aksis HPA yang berkaitan dengan aktivasi berbagai sitokin termasuk TNF- $\alpha$ yang tergolong "key immune modulator". Hal ini terbukti dari skor (nilai) agregasi limfosit yang tinggi pada renjatan listrik (2,13 atau 30\%) dibandingkan dengan kontrol (1,41 atau $19,85 \%$ ). Juga terbukti dari jumlah titik lokal sekresi TNF- $\alpha$ di lambung untuk renjatan listrik $(69,23 \%)$ yang lebih tinggi dari kontrol (30,07\%).

Hasil temuan keenam ("F") membuktikan, bahwa stresor fisik (RL) menimbulkan distres dengan manifestasi perubahan berat badan. Pada minggu pertama paparan stresor terjadi distres disertai dengan penurunan berat badan, yang identik dengan terjadinya anoreksia nervosa pada manusia. Sedangkan pada minggu kedua, ketiga dan keempat paparan stresor terjadilah distres yang disertai dengan peningkatan berat badan melalui mekanisme adaptasi dan kompensasi yang identik dengan terjadinya bulimia nervosa pada manusia (Charney dan Nestler, 2004).

Berdasarkan hasil penelitian, pengkajian parameterparameter yang diperoleh serta pembahasan umum, maka dapat diambil kesimpulan sebagai berikut. (1) Didapatkan adanya pengaruh renjatan listrik terhadap konsentrasi IL-6 dan Kortisol plasma. Hasil temuan pertama ini membuktikan, stresor fisik menyebabkan perubahan fungsi dan struktur hipokampus, melalui peran kortisol dan IL-6 plasma, yang terbukti dari peningkatan kadarnya di plasma. IL-6 lebih responsif terhadap stresor kejiwaan (peningkatan lebih tinggi 70,16\%), merupakan suatu 
temuan penelitian yang baru. (2) Ada pengaruh peningkatan konsentrasi IL-6 dan kortisol plasma, pada peningkatkan distribusi IL-6 dan kortisol hipokampus. Peningkatan konsentrasi IL-6 di plasma meningkatkan distribusi IL-6 hipokampus $63,79 \%$ serta distribusi kortisol hipokampus $77,86 \%$, sedangkan peningkatan konsentrasi kortisol plasma meningkatkan distribusi IL-6 hipokampus 38,19\% dan distribusi kortisol hipokampus 41,98\%. Hasil temuan kedua membuktikan, peran IL-6 sebagai mediator stres lebih dominan dibandingkan dengan kortisol, mengingat IL-6 plasma dapat meningkatkan distribusi IL-6 maupun kortisol hipokampus lebih tinggi (77,86\%). Data ini merupakan suatu temuan penelitian yang baru (penelitian yang lama kortisol). (3) Peningkatan distribusi IL-6 dan kortisol hipokampus, terbukti meningkatkan juga distribusi SERT dan indeks apoptosis hipokampus; mengingat korelasi yang kuat dan positif antara distribusi IL-6 hipokampus dengan distribusi SERT hipokampus (nilai korelasi $\mathrm{r}=0,873$ ), antara distribusi IL-6 hipokampus dengan indeks apoptosis hipokampus $(\mathrm{r}=0,881)$, antara distribusi kortisol hipokampus dengan distribusi SERT hipokampus $(\mathrm{r}=0,864)$, antara distribusi kortisol hipokampus dengan indeks apoptosis hipokampus $(\mathrm{r}=0,900)$. Peningkatan distribusi IL-6 hipokampus meningkatkan distribusi SERT hipokampus $(87,73 \%)$ dan indeks apoptosis hipokampus $(67,49 \%)$. Peningkatan distribusi kortisol hipokampus meningkatkan distribusi SERT hipokampus $85,68 \%$ serta indeks apoptosis hipokampus $114,00 \%$. Hasil temuan ketiga ini membuktikan, kortisol secara langsung mengakibatkan perubahan struktur hipokampus. Sedangkan IL-6 lebih lemah dalam menimbulkan apoptosis, IL-6 lebih cenderung neuroprotektif. Hasil temuan ketiga ini sesuai dengan penelitian terdahulu. (4) Penelitian ini juga membuktikan, peningkatan distribusi SERT dan indeks apoptosis hipokampus mempunyai korelasi positif dengan berat badan tikus. Temuan ini membuktikan bahwa berbagai stresor akan menimbulkan distres dengan gradasi yang kurang lebih sama, melalui gangguan fungsi dan struktur hipokampus dengan tingkatan yang sama pula. (5) Terbukti ada korelasi positif antara renjatan listrik dengan berat badan tikus. Renjatan listrik mempunyai korelasi positif dengan penurunan berat badan tikus (14,15\%) pada minggu pertama perlakuan, sedangkan pada minggu kedua meningkat $13,22 \%$ dan minggu ke tiga dan empat meningkat $11,46 \%$. Pada minggu pertama paparan stresor, terjadi distres yang disertai dengan penurunan berat, yang identik dengan terjadinya anoreksia nervosa pada manusia. Sedangkan pada minggu kedua, ketiga dan keempat paparan stresor terjadilah distres yang disertai dengan peningkatan berat badan terkait dengan mekanisme adaptasi dan kompensasi, yang identik dengan terjadinya bulimia nervosa pada manusia.

Selain enam temuan di atas, ditemukan pula: (1) Patofisologi yang berbeda dengan stresor fisik, pada stresor psikologis terbukti peran malfungsi neurotransmisi serotonergik lebih dominan. Pada penelitian lain, stresor fisik melalui peran IL-6 dan kortisol. (2) Peran yang lebih dominan dari IL-6 pada proses mediasi terjadinya distres, dibandingkan dengan peran kortisol.

Fenomena baru yang ditemukan dalam penelitian ini adalah adanya hubungan erat antara transporter serotonin (SERT) dengan apoptosis regio CA3 hipokamous, TNF- $\alpha$ gaster dan distres, yang mendukung: (1) Korelasi signifikan antara distres dengan perubahan SERT dan apoptosis regio $\mathrm{CA} 3$ hipokampus maupun perubahan TNF- $\alpha$ gaster. (2) Hipotesis baru tentang patomekanisme atau patofisiologi distres (juga gangguan jiwa yang lain) secara molekuler yang berlandaskan pada "multimalfungsi neurotransmisi sentral".

Pada penelitian ini telah dapat dibuktkan bahwa transporter serotonin (SERT), IL - 6, kortisol dan TNF- $\alpha$ dapat dimanfaatkan untuk menegakkan diagnosis molekuler (diagnosis genotipik) dari suatu gangguan kejiwaan, serta untuk melengkapi pertimbangan terapi penyakit menahun yang resisten terapi (misalnya, gastritis kronis). Akan tetapi manfaat tersebut masih dapat lebih ditingkatkan lagi kualitasnya dengan penelitian lanjutan; oleh karenanya disarankan untuk dilakukan: (1) Kajian lebih lanjut yang meneliti korelasi antara afinitas dan densitas transporterserotonin trombosit dengan perubahan fungsi dan struktur hipokampus (malfungsi SERT \& Apoptosis regio CA3 hipokampus; secara in vivo, bersifat kuantitatif). (2) Kajian lebih lanjut mengenai peran glutamat, dan transporter neurotransmisi lain, dalam patofisiologi gangguan jiwa pada hewan coba; penelitian diperluas ke area otak lainnya seperti raphe dorsalis, locus coeruleus dan area prefrontalis (in vivo). (3) Disamping itu disarankan peningkatan fasilitas dan peningkatan jumlah pakar laboratorium (laboran) di laboratorium biomedik fakultas kedokteran Universitas Brawijaya, konkritnya fasilitas pemeriksaan radioaktif (ligand binding) untuk mendukung penelitian lebih lanjut tentang kemungkinan penggunaan transporter-serotonin trombosit sebagai prediktor laboratoris gangguan jiwa yang lebih bersifat lebih akurat dan sederhana.

\section{KEPUSTAKAAN}

Bleich A, Brown SL, Kahn R, van Praag HM, 1988. The role of serotonin in schizophrenia. Schizophr Bull; 14: 297-315. 
Charney DS, Nestler EJ, 2004. Neurobiology of Mental Illness. $2^{\text {nd }}$ Oxford University Press, Inc. New York.

Dubovsky SL, Thomas M, 1995. Serotonergic Mechanisms and Current and Future Psychiatric Practice.Journal Clinical Psychiatry. 56 (suppl 2): 38-48.

Duman RS, 2002. Pathophysiology of depression: the concept of synaptic plasticity. Eur Psychiatry; 17 suppl 3: 306-310.

Dunn AJ, 2000. Cytokine Activation of the HPA Axis. Annals of the New York Academy of Sciences. 917:608-617

Figueiredo HF, Bodie, BL Tauchi MC, Mark Dolgas, Herman JP, 2003. Stress Integration after Acute and Chronic Predator Stress: Differential Activation of Central Stress Circuitry and Sensitization of the Hypothalamo-Pituitary-Adrenocortical Axis. Endocrinology; 144(12): 5249-5258

Fuchs E, Czeh B, Michaelis T, de Biurrun G, Watanabe T, Frahm J. 2002. Synaptic plasticity and tianeptine: structural regulation. Eur Psychiatry; 17 suppl 3: 311-317.

Ganong WF, 1995. Review of Medical Physiology. 17th ed., Appleton \& Lange, Norwalk, Connecticut. 251-261, 368-369.

Halperin JM, Sharma V, Siever LJ, Schwartz ST, Matier K, Wornell G, Newcorn JH, 1994. Serotonergic function in aggressive and nonaggressive boys with attention deficit hyperactivity disorder. Am J Psychiat.[abstract]. 151(2): 243-248

Hindmarch I, 2001. Expanding the horizons of depression: beyond the monoamine hypothesis. Hum Psychopharmacol Clin Exp; 16: 203-218

Hindmarch I, 2002. Beyond the monoamine hypothesis: mechanisms, molecules, and methods.Eur Psychiatry, 17 [suppl\} 3: 294-32.

Jackson IM, Luo LG, 1998. Antidepressants inhibit the glucocorticoid stimulation of TRH expression in cultured hypothalamic neurons. $J$ Invest Med; 46: 470-4.

Jackson IM, 1998. The thyroid axis and depression. Thyroid; 8: 951-6.

Jie-Guang Chen and Gary Rudnick, 2000. Permeation and gating residues in serotonin transporter Proc Natl Acad Sci USA. February 1; 97(3): 1044-1049.

Joseph R, Tsering C, Grumfeld S, Welch KMA, 1992. Serotonin may have neurotoxic properties. Neurosci Lett; 136: 15-18.

Kasper S, 1999. Bridging the gap between psychopharmacology and clinical symptoms. International Journal of Psychiatry in Clinical Practise 3 [suppl 2]: S17-S20.

Kronfol Z, Remick DG, 2000. Cytokines and the brain: implications for clinical psychiatry. Am J Psychiat.[abstract]. 157(5): 683-694.

Kumar AM, Weiss S, Fernandez JB, Cruess D, Eisdorfer C, 1998. Peripheral serotonin level in women: role of aging and ethnicity. Gerontology.[abstract]. 44(4): 211-216.

Levine ES, Black IB, 2000, Neurotropic factors. In: Comprehensive Textbook of Psychiatry, $7^{\text {th }}$ ed, Sadock BJ, Sadock VA edit, Lippincott Williams \& Wilkins, A Wolters Kluwer Company, 71-75.

Liposits ZC, Paull WK, 1987 Synaptic interaction of serotonergic axons and corticotropin releasing factor (CRF) synthesizing neurons in the hypothalamic paraventricular nucleus of the rat; A light and electron microscopic immunocytochemical study. Hystochemistry, 86: 541-549.

Magarinos AM, Antoine D, McEwen BS, 1999. Effects of antidepressants and benzodiazepine treatments on the dendritic structure of CA3 pyramidal neurons after chronic stress. European Journal of Pharmacology. 371(2-3). 113-122.

McEwen BS, 1997. Possible mechanisme for atrophy of the human hippocampus. Molecular Psychiatry, 2: 255-262.

McEwen BS, Magarinos AM, Reagan LP, 2002. Structural plasticity and tianeptine: cellular and molecular targets. Eur Psychiatry; 17 [suppl. 3]; 318s-330s.

McEwen BS, 1999. Stress and hippocampal plasticity. Ann. Rev. Neurosci.[abstract]. 22: 105-122.

McEwen BS, 1994. Adrenal steroids, the hippocampus, and the amygdala: relationship to anxiety and depression. Medicographia, 16: 60-63.

McKittrick CR, Magarinos AM, Blanchard DC, Blanchard RJ, McEwen BS, Sakai RR, 1996. Chronic social stress decreases binding to 5-HT transporter sites and reduces dendritic arbors in CA3 of hippocampus. Abstr Soc Neurosci; 22: 809-818.

McKittrick CR, Magarinos AM, Blanchard DC, Blanchard RJ, McEwen BS, Sakai RR, 2000. Chronic social stress reduces dendritic arbors in CA3 of hippocampus and decreases binding to serotonin tranporter sites. Synapse; 36: 85-94.

Montanez S, Daws LC, Gould GG, Frazer A, 2003. Serotonin (5HT) transporter (SERT) function after graded destruction of serotonergic neurons. J Neurochem; 87(4): 861-7.

Morilak DA, Garlow SJ, Ciaranello RD, 1993. Immunocytochemical localization and description of neurons expressing $5-\mathrm{HT}_{2}$ receptors in the rat brain. Neuroscience. 54: 701-717.

Niimi M, Wada Y, Sato M, Takahara J, Kawanishi K, 1996. Effect of continuous intravenous injection of interleukin- 6 and pretreatment with cyclooxygenase inhibitor on brain c-fos expression in the rat. J Neuroendocrinology.[abstract].66: $47-53$.

Nutt DJ, 2002. The neuropharmacology of serotonin and noradrenaline in depression. International Clinical Psychopharmacology. 17 [suppl]: S1-S12

Papanicolaou DA, Wilder RL, Manolagas SC, Chrousos GP, 1998. The pathophysiologic roles of interleukin-6 in human disease. Ann Intern Med. 128:127-137.

Papanicolaou DA, 2000. Interleukin-6: The Endocrine Cytokine. The Journal of Clinical Endocrinology \& Metabolism; 85(3): 1331-1333.

Rivier C, 1995. Mechanisms of altered prolactin secretion due to the administration of interleukin-1 beta into the brain ventricles of the rat. Neuroendocrinology.[abstract]. 62(2): 198-206.

Turnbull AV, Rivier CL, 1999. Regulation of the hypothalamicpituitary-adrenal axis by cytokines: actions and mechanisms of action. Physiol Rev 79: 1-71.

Reviewer: Prof. Win Darmanto, Drs., M.Si., Ph.D 